\title{
Perkawinan Siri dalam Reformulasi Hukum Perkawinan Islam Di Indonesia Sebagai Upaya Preventif Terhadap Disharmoni Sosial dalam Masyarakat (Perspektif Gender dan Hak Asasi Manusia)
}

\author{
Zeni Lutfiyah, Agus Rianto, M. Rasyid Ridlo \\ Dosen Fakultas Hukum Universitas Sebelas Maret Surakarta \\ zeniluthfiyah@yahoo.co.id
}

\begin{abstract}
This research investigates the reality of marriage laws in Indonesia, especially related to nikah siri or unregistered marriage.The study used a gender perspective and human rights, in particular the rules contained in the Act No. 1 of 1974 and the Compilation of Islamic Law. It is based on the assumption that the number of rules indicates gender bias and poor protective of humanity and justicevalues. Even so this study will measure the chances of the Preliminary Draft of Material Law of Islamic Court/Rancangan Undang-Undang Hukum Materiil Peradilan Agama (RUUHMPA) as a model of reformulation Indonesian marriage law to accommodate and be a legal solution for the types of gender inequality and human rights, especially with regard to the prevention of lameness and imbalance values of justice and humanity. This type of research is classified in the normative legal research for reviewing the articles of a rule of positive law by using normative methodological approach, which analyzes the legal formulations and alignment between the article and is mainly used to analyze the validity of the conceptual formulation of the law before the benchmarks used assessment gender and human rights in the realm of social science studies. This study concluded that in the articles of the Act.No. 11974 and Compilation of Islamic Law there are still many weaknesses, especially with regard to gender issues and human rights, which include the impact on the rampant cases of unregistered marriage or nikah siri which is one form of harassment against the institution of marriage, it is also due to the lack of provision of criminal sanctions in this legislation. While the Draft of Material Islamic Courts (RUU HMPA) is a model that is offered and expected as breaking the deadlock the relationship between religion and culture. In particular to provide protection for women and children are quite vulnerable to acts of discrimination. Nevertheless the draft still needs to be examined and refined to be more able to give justice to every citizen of Indonesia.
\end{abstract}

Keywords: Reformulation, Marriage, Gender, Human Rights.

\begin{abstract}
Abstrak
Penelitian ini berusaha melihat realitas peraturan tentang perkawinan di Indonesia terutama yang berkaitan dengan perkawinan siri atau perkawinan bawah tangan.Kajian ini menggunakan perspektif gender dan Hak Asasi Manusia, khususnya peraturan yang terdapat dalam Undang-Undang No. 1 Tahun 1974 dan Kompilasi Hukum Islam. Hal ini didasarkan pada asumsi banyaknya peraturan yang bias gender dan kurang melindungi nilai kemanusiaan dan keadilan. Demikan juga penelitian ini akan mengukur peluang Rancangan Undang-Undang Hukum Materiil Pengadilan Agama (RUU HMPA) sebagai model reformulasi hukum perkawinan Indonesia dalam mengakomodir dan menjadi solusi hukum atas bentuk-bentuk ketidak setaraan gender dan Hak Asasi Manusia terutama berkaitan dengan pencegahan dari ketimpangan nilai-nilai keadilan dan kemanusiaan.Jenis Penelitian ini termasuk dalam penelitian hukum normatif karena mengkaji pasal-pasal sebuah aturan hukum positif dengan menggunakan pendekatan normatif metodologis, yaitu menganalisis rumusan-rumusan hukum dan keselarasan antarpasal dan terutama digunakan untuk menganalisis validitas konseptual rumusan hukum
\end{abstract}


tersebut di hadapan tolok ukur yang digunakan kajian gender dan HAM yang masuk dalam ranah kajian ilmu sosial. Dari penelitian inidisimpulkan bahwa di dalam pasal-pasal UU. No. 1 tahun 1974 dan Kompilasi hukum Islam masih terdapat banyak kelemahan terutama yang berkaitan dengan isu Gender dan HAM, yang diantaranya berdampak pada maraknya kasus perkawinan siri atau perkawinan bawah tangan yang merupakan salah satu bentuk pelecehan terhadap lembaga perkawinan, hal ini juga dikarenakan belum adanya ketentuan sanksi pidanadalam perundang-undangan ini.Sedangkan Rancangan Undang-Undang Hukum Materii Peradilan Agama (RUU HMPA) merupakan model yang ditawarkan dan diharapkan sebagai pemecah kebuntuan hubungan antara agama dan kebudayaan.Khususnya untuk memberikan perlindungan bagi perempuan dan anak yang cukup rentan terhadap tindak diskriminasi.Meski demikian Rancangan Undang-Undang ini masih perlu dicermati dan di sempurnakan supaya lebih dapat memenuhi rasa keadilan bagi setiap warga negara Indonesia.

Kata Kunci: Reformulasi, Perkawinan, Gender, Hak Asasi Manusia.

\section{A. Pendahuluan}

Maraknya beberapa kasus yang Mencerminkan lemahnya hukum perkawinan Indonesia dalam menjerat tindakan pelecehan lembaga perkawinan tercermin dari maraknya kasus-kasus perkawinan, seperti contoh kasus Machicha Mochtar sebagai akibat perkawinan bawah tangan, kasus Syeh Puji karena adanya perkawinan bawah umur dan yang terakhir kasus Aceng Fikri sang bupati Garut karena ketidak seriusan dalam menjalankan perkawinan atau melakukan perkawinan siri. Dari seluruh peristiwa perkawinan tersebut isu genderlah yang paling kuat menjadi perbincangan, dan butuh segera di tuntaskan permasalahannya.

Maka menurut pandangan para tokoh berperspektif gender, masalah perkawinan yang terdapat dalam Undang-Undang Perkawinan No. 1 Tahun 1974, merupakan bentuk-bentuk pandangan dan pengkonsepsian yang secara kultural dan sosiologis telah melakukan diskriminasi terhadap perempuan (Mulia, 2007). Diskriminasi terhadap perempuan tersebut terjadi karena ketimpangan gender, yaitu konstruksi sosial dan kultural yang membedakan peran, perilaku, mentalitas, dan karakteristik emosional antara laki-laki dan perempuan yang berkembang di masyarakat (Fakih,1999). Juga dikarenakan adanya ketidaklengkapan pasal-pasal terkait,sehingga menyebabkan munculnya sebuah permasalahan yang terus berkembang.

Sedangkan dalam ajaran Islam, posisi laki-laki dan perempuan adalah setara sebagai manusia, makhluk yang mempunyai tugas sebagai hamba dan khalifah Allah di muka bumi. Hal ini didasarka pada beberapa ayat al-Qur'an seperti surat Shad (38:71), surat Yunus (10:44), alBaqoroh (2:48) dan masih banyak lagi ayat al-Qur’an yang menyiratkan adanya kesetaraan lakilaki dan perempuan dalam meningkatkan kualitas iman dan perbuatan baiknya dalam tugas kemanusiaan di bumi. Perbedaannya hanya menunjuk pada aspek biologis, yang mana dalam ajaran islam perbedaan biologis tidak bisa dijadikan alasan untuk melakukan diskriminasi (Mulia, 2007:). 
Oleh karena itu jika terjadi produk hukum (fikih) yang tidak sensitif dengan hakekat tujuan syari’ah, maka perlu dilakukan pengkajian ulang. Hal ini didasarkan pada beberapa hal pokok yaitu: pertama, hakekatnya Islam sendiri sebagai bentuk respon sosial terhadap masyarakat, kedua Islam sebagai ajaran yang menjanjikan kebahagiaan dan kesejahteraan bagi manusia. Demikian juga kehadiran Kompilasi Hukum Islam merupakan salah satu kelengkapan kelembagaan Peradilan Agama yang memegang kompetensi hukum kekeluargaan Islam yang telah diundangkan terlebih dahulu, sehingga bagaimana sebuah peradilan dapat beroperasi secara wajar, adil dan berkeadilan jika tidak disertai dengan hukum materiil sebagai pegangan yang bersifat unifikatif. Maka kehadirannya merupakan kebutuhan yang tidak dapat ditawar-tawar lagi bagi tegaknya kelembagaan Peradilan Agama.

Namun untuk memenuhi segala kebutuhan hukum positif yang dihadapi umat Islam dan pengadilan tidaklah mudah, hal ini disebabkan tidak seluruh kasus yang diajukan dalam persidangan itu dapat dirujuk dalam dalil-dalil hukum Islam, sehingga penyusunan Kompilasi inipun mengalami kendala yang sama, apalagi sifat unik budaya dan adat Indonesia yang sangat kental menghiasi praktek hukum kekeluargaan dalam masyarakat. Maka untuk dalil-dalil yang semacam itu ditetapkan dengan landasan maslahah bagi dalil-dalil yang berkategori zanni (relative).

Dalam hal perundangan yang terkait dengan perkawianan di Indonesia adalah Peraturan Pemerintah No. 1 tahun 1974 tentang perkawinan, PP No. 9 Tahun 1975 tentang perceraian, UU No 88 tahun 2002 tentang penghapusan traffiking perempuan dan anak, UU No. 23 tahun 2004 tentang Kekerasan dalam Rumah Tangga (KDRT). Selain peraturan dan Undang-undang tersebut juga dipakai rencana revisi PP No. 1 tahun 1974, yang sampai saat ini belum disahkan oleh presiden. Demikian juga digunakan Counter Legal Draf (CLD) Kompilasi Hukum Islam (KHI) tahun 2004 dari PUG Depag RI, kedua hukum perundang-undangan yang masih berupa rancangan ini akan dijadikan sebagai penyeimbang dalam melihat kondisi sosial di lapangan. Sehubungan dengan itu negara juga sudah menggodok Rancangan Undang-Undang Hukum Materiil Peradilan Agama (RUUHMPA) yang secara tegas di dalamnya mengatur tentang poligami, perkawinan kontrak atau mut'ah, wali yang tidak berhak dan termasuk perkawinan siri. Dalam pasal 143 RUU ini menyebutkan bahwa jika seseorang melakukan kawin siri atau kawin kontrak dapat diancam dengan pidana penjara. Meski RUU ini menuai polemik dari banyak kalangan karena dianggap negara terlalu menerobos batas syari'ah Islam dan hukum formal , namun demi kepastian hukum RUU ini telah masuk dalam Program Lagislasi Nasional (Prolegnas). 
RUUHMPA (Rancangan UndangUndang Hukum Materiil Peradilan Agama) menjadi salah satu solusi dan alternative yang di tawarkan untuk mereformulasi undang-Undang No. 1 tahun 1974. RUU ini memuat aturan- aturan yang relatif lebih maju dengan menyajikan rumusan pemidanaan pada beberapa pasal berkaitan dengan pencatatan nikah, poligami, dan nikah siri, namun kecenderungan RUU HMPA tersebut sebagai sebuah jawaban atas problematika hukum perkawinan di Indonesia masih bersifat administratif dan belum memiliki rajutan yang kuat dengan peluang realisasinya secara nyata di lapangan. Problem hukum acara sebagaimana yang menimpa proses eksekusi hak nafkah anak dan isteri korban perceraian, gono gini, dan lain-lain barangkali masih akan membayangi rumusan usulan RUU ini.

\section{B. Metode Penelitian}

Jenis penelitian ini termasuk dalam penelitian hukum normatif karena mengkaji aturan hukum positif, dengan menggunakan tolok ukur doktrin/asas hukum Islam yang sarana utamanya merupakan dasar konseptual pembentukan, penetapan dan pengkajian hukum Islam. Lebih jelasnya penelitian ini termasuk dalam bidang kajian penelitian perundang-undangan yang sering diistilahkan dengan kitab hukum. Adapun eksistensi studi kasus dalam penelitian ini tidak dimaksudkan untuk melakukan penelitian empirik, tapi lebih diarahkan pada penelitian terhadap dokumentasi guna melengkapi basis data pendukung analisis metodologis, sekaligus menjajagi implikasi sebuah ketentuan hukum positif.

Penelitian ini menggunakan pendekatan normatif Metodologis, hal ini terutama digunakan untuk menganalisis rumusan-rumusan hukum dan keselarasannya satu sama lain Karena penelitian ini merupakan penelitian kepustakaan (library research) yang mengeksploitasi sumber-sumber kepustakaan dalam bidang khusus terkait dengan penelitian ini, maka sumber data primer penelitian ini adalah ayat-ayat hukum dari Al-Qur'an dan Hadist, Kompilasi Hukum Islam, dan Undang-undang No. 1 tahun 1974. dan perundangan lain yang berkaitan dengan pernikahan siri. Sedangkan hukum keluarga Islam positif di Indonesia, kitab-kitab fiqh dan kitab yang membahas beberapa metodologi terkait dengan Fikih munakahat diposisikan sebagai sumber sekunder termasuk pendapat-pendapat para mufassir terhadap ayat-ayat yang terkait dengan pembahasan penelitian ini. Tulisan-tulisan mengenai Kompilasi Hukum Islam, hukum perkawinan dan metodologi hukum Islam secara umum yang tidak bersinggungan langsung dengan topik ditempatkan sebagai sumber data tersier. Analisis data yang dipakai adalah analisa hukum normatif dengan teknik uji validasi. Analisa ini dilakukan dengan menelaah topik penelitian ini dengan menggunakan ukuran-ukuran atau kaidah-kaidah yang ada dalam hukum 
normatif. Hasil dari analisa ini adalah sebuah justifikasi apakah sesuatu berjalan sesuai hukum atau tidak. Penelitian ini mengasumsikan bahwa pernikahan siri akan menimbulkan banyak dampak negatif karena tidak sesuai dengan aturan hukum. Atas dasar temuan yang dibeberkan secara terperinci tentang hal tersebut kemudian dilakukan penelaahan lanjutan untuk mencari jalan keluar atas problem hukum yang ditemukan.

\section{Hasil Penelitian Dan Pembahasan}

\section{Tinjauan tentang Hukum Perkawinan Islam di Indonesia}

Dengan ditetapkannya UU No. 1 Tahun 1974 tentang perkawinan, maka dasar berlakunya Hukum Islam di bidang perkawinan, talak dan rujuk adalah UU No.1 Tahun 1974, terutama Pasal 2 ayat 1 dan Pasal 2 ayat 2 yang berbunyi sebagai berikut :"Perkawinan adalah sah, apabila dilakukan menurut hukum masing-masing agamanya dan kepercayaannya itu. Tiap-tiap perkawinan dicatat menurut Peraturan Perundang-Undangan yang berlaku”. Berdasarkan teks alQur'an dan al-Hadist, syarat-syarat sahnya suatu perkawinan adalah: pertama, adanya dua calon mempelai yang boleh dan mau menikah. Kedua, adanya kerelaan dua pihak. Ketiga, adanya wali bagi mempelai perempuan. Keempat, adanya dua orang saksi. Kelima, adanya ijab dan Kabul. Keenam, dengan mahar tertentu.

Redaksi teks-teks tersebut adalah sebagai berikut:

a. Adanya calon mempelai. Syarat calon mempelai ini yakni bukan yang haram dinikahi, baik karena hubungan nasab (Shahih Muslim:2.619), hubungan sepersusuan (Shahih Bukhori :2.874), hubungan perkawinan (Sahih Bukhori: 18.166), maupun karena berbeda agama sebagaimana (surat an-Nisa :2324).

b. Adanya kerelaan dua pihak (Sahih Muslim: 2.543). sebagaimana dijelaskan dalam hadist nabi bersabda ” ...Janganlah janda dinikahkan kecuali atas kemauannya, dan janganlah gadis dinikahkan kecuali atas kerelaannya, dan diamnya adalah ijinnya”.

c. Adanya wali (Sunan Turmudhi: 1.020), adanya wali merupakan persyaratan sahnya pernikahan, sebagaimana hadist nabi”..tidak ada pernikahan yang tanpa walinya...” hukum perkawinan di Indonesia menetapkan wali sebagai salah satu rukun nikah. Tanpa wali pernikahan dinilai tidak sah. Hal ini didasarkan pada pandangan mayoritas ulama fikih kecuali Hanafiyah yang tidak mewajibkan adanya wali bagi sebuah pernikahan manakala pilihan anak sesuai dengan pilihan wali, keduanya secara ihlas dinikahkan dan menikahkan. 
d. Adanya saksi. Kehadiran dua orang saksi merupakan salah satu syarat sahnya pernikahan. Fungsi dari persaksian ini adalah untuk dua hal, yakni pengumuman dan penerimaan nikah (ijab Kabul).

e. Adanya Ijab Kabul. Proses penyerahan perempuan kepada laki-laki yang menikahi merupakan proses terakhir pernikahan. Setelah akad diucapkan oleh wali dan dijawab oleh mempelai pria, maka perkawinan telah menjadi sah. Demikian ritual perkawinan menurut Hukum Islam.

f. Adanya Mahar. Mahar adalah nama dari pemberian yang diberikan mempelai laki-laki kepada perempuan, karena terjadinya akad nikah. Penetapan hukum bagi sahnya sebuah perkawinan di Indonesia adalah dengan pembayaran maskawin atau mahar.

Maka berdasar keterangan diatas, dapat diambil pengertian bahwa suatu pernikahan dianggap sah jika telah terpenuhi enam syarat diatas, ditambah harus dicatatkan. Bahkan menurut sebagian ulama fikih pernikahan sudah dianggap sah jika memenuhi empat persyaratan: ada mempelai laki-laki dan perempuan, ada wali yang menikahkan pihak perempuan, ada dua orang saksi, dan ada maskawin. Dari penjelasan di atas bukan berarti bahwa pencatatan pernikahan bukan termasuk suatu persyaratan, tetapi telah masuk dalam aturan perundangan tentang keabsahan pernikahan Islam di Indonesia.

\section{Tinjauan Tentang Pernikahan Siri}

Teks dari al-Qur'an maupun Hadist yang membahas tentang larangan nikah siri secara eksplisit memang tidak ada. Namun secara implisit ada tiga hadist yang terkait dengan larangan terhadap nikah siri, yakni pertama, anjuran Nabi agar mengumumkan pernikahan, kedua, ketidaksukaan nabi merahasiakan pernikahan, ketiga, anjuran Nabi agar mengadakan walimah (perayaan nikah).

Anjuran untuk mengumumkan pernikahan terdapat dalam riwayat Ibnu Majah:”... Dari 'Aisyah r.a , bahwasanya Rasulullah bersabda: umumkan pernikahan ini dan pukullah rebana”(Sunan Ibnu Majah:1.885, Sunan Turmudhi:1.109, Musnad Ahmad:15.545). Tentang ketidaksukaan Nabi terhadap pernikahan yang dirahasiakan, terlihat dalam hadist berikut (Musnad ahmad: 16.113) “... Dari abu Hasan, bahwasanya Nabi SAW membenci nikah yang dirahasiakan”. Sedangkan ketentuan adanya walimah terdapat dalam hadist “...dari anas berkata: Bahwa Rasulullah SAW membebaskan Shafiyyah dan pembebasannya sebagai maharnya serta mengadakan walimah dengan seekor kambing” (Shahih Bukhori). 
Demikian juga Makna dan Tujuan Perkawinan dalam Peraturan Perundang-undangan di Indonesia adalah berangkat dari makna pernikahan, yaitu merupakan akad yang sangat kuat atau mistaqon gholidzon untuk mentaati perintah Allah dan melaksanakannya. merupakan ibadah. Dalam pasal 1 Undang-Undang Nomor 1 Tahun 1974 disebutkan bahwa "perkawinan ialah ikatan lahir batin antara pria dengan seorang wanita sebagai suami istri dengan tujuan membentuk keluarga (rumah tangga) yang bahagia kekal berdasarkan Ketuhanan Yang Maha Esa”. Sedang dalam Kompilasi Hukum Islam pada bab II (dasar-dasar perkawinan) pasal 3, disebutkan bahwa perkawinan bertujuan untuk mewujudkan kehidupan rumah tangga yang sakinah mawaddah warohmah(Hilman Hadikusuma,1990:7).

Sedangkan pernikahan siri, berasal dari kata "sirri” atau "sir” bermakna rahasia, yakni tidak ditampakkan. Nikah siri (Arab;:nikah sirri) adalah nikah “diam-diam”, tidak menggunakan resepsi dan semua pihak terkait (baik wali, saksi maupun kedua mempelai) sepakat untuk merahasiakannya. Hal ini berarti unsure mistaqon gholidzon yang sangat ditekankan dalam perkawinan tersebut sulit terpenuhi dengan tidak adanya keterbukaan dan bukti legalitasny. Demikian juga tujuan perkawinan untuk membina rumah tangga atau keluarga yang bahagia berdasarkan ketuhanan yang maha esa menjadi sulit diwujudkan karena secara jelas perkawianan tersebut diangga tidak sah oleh negara. sehingga pernikahan yang tidak dicatatkan, akan menimbulkan banyak kemadlorotan terutama bagi istri dan anak-anak dari pernikahan siri tersebut. Nikah siri yang lebih dikenal dengan istilah nikah di bawah tangan ini tidak diakui oleh negara karena tidak dicatatkan di Kantor Urusan Agama (KUA), meskipun bisa dianggap sah menurut hukum agama Islam asal syarat dan rukun nikahnya terpenuhi.

Secara umum pernikahan siri mempunyai karakteristik sebagai berikut:

1. Pernikahan tanpa wali. Yaitu pernikahan yang dilakukan secara rahasia karena pihak wali perempuan tidak setuju, atau karena menganggap sah pernikahan tanpa wali. atau hanya karena ingin menurutkan nafsu syahwat belaka tanpa mengindahkan ketentuan syari’at islam.

2. Pernikahan yang sah menurut agama karena terpenuhi syarat dan rukunnya namun tidak dicatatkan dalam lembaga pencatatan negara yang disebut KUA. Banyak faktor yang menyebabkan seseorang tidak mencatatkan pernikahannya di lembaga pencatatan sipil negara, ada yang karena faktor biaya karena tidak mampu membayar administrasi pencatatan, ada pula karena takut ketahuan melanggar aturan Untuk yang melarang Pegawai Negeri nikah lebih dari satu dan lain sebagainya.Untuk kasus semacam ini ada dua hukum yang harus dikaji secara berbeda; yakni pertama, hukum pernikahannya dan kedua, hukum tidak memcatatkan pernikahannya. Dari aspek pernikahannya, jika pernikahan tersebut telah 
terpenuhi syarat dan rukunnya secara hukum islam, maka pernikahan tersebut tetap sah menurut ketentuan syari’at, dan pelakunya tidak dianggap melakukan perbuatan dosa.

3. Pernikahan yang dirahasiakan karena pertimbangan-pertimbangan tertentu misalnya karena takut adanya stigma negatif dari masyarakat yang sudah menganggap tabu pernikahan siri, atau karena pertimbangan-pertimbangan yang rumit lain yang memaksa seseorang untuk merahasiakan pernikahanya.

4. Nikah siri dalam pandangan agama diperbolehkan sepanjang hal-hal yang menjadi rukunnya terpenuhi. Dan sepanjang dalam melakukan atau menjalani pernikahan tersebut tidak banyak mudharat (efek buruk) yang terjadi. Namun perbedaannya adalah tidak mempunyai bukti otentik bila telah menikah atau dengan kata lain tidak mempunyai surat sah sebagai seorang warga negara yang mempunyai kedudukan yang kuat di dalam hukum. Nikah siri, meskipun dalam legal Islam bisa disahkan, namun dalam legal negara bisa tidak sah.

Pemaknaan terhadap pernikahan secara syar'i dari hadist-hadist di atas memang secara eksplisit tidak ada anjuran untuk mencatat suatu pernikahan, dan pada masa nabi dan periode awal islam pencatatan nikah belum dan tidak dilakukan. hal ini bisa dimaklumi karena sarana alat tulis, kemampuan tulis-menulis pada waktu itu belum berkembang, dan permasalahan masyarakat belum begitu komplek. Legalitas formal pada masa nabi adalah keberadaan Nabi itu sendiri, keberadaan Nabi sebagai imam dan khalifah menjadi justifikasi keabsahan suatu pernikahan yang terjadi pada masa itu. Pengakuan Nabi atas terjadinya suatu pernikahan dianggap sebagai bukti legalitas formal.

Sementara dalam kondisi sekarang ini, kebutuhan bukti legal formal berbagai macam bukti identitas seseorang mulai dari akta kelahiran, KTP, Kartu kekuarga, akta pernikahan,SIM, Ijazah, bukti-bukti kepemilikan, dan lain-lain merupakan kebutuhan primer akan eksistensi seseorang untuk menjaga hakhaknya. Artinya tanpa adanya bukti-bukti otentik seperti berbagai macam identitas tersebut, hak-hak seseorang menjadi hilang di depan hukum positif di Indonesia. Demikian juga jika seseorang telah menikah, namun jika tidak mempunyai bukti akta nikah, maka status masingmasing sebagai suami atau istri dalam hukum positif tidak diakui, begitu pula anak-anak yang dilahirkan dari pernikahan tersebut, sehingga hak-hak mereka tidak mendapat perlindungan hukum.

Demikian juga, Islam mengajarkan untuk selain mentaati Allah dan RasulNya, juga wajib mentaati hukurn negerinya sebatas negaranya tidak melakukan kesyirikan. Nikah siri dianggap batal demi hukum, baik dan segi hukum positif di Indonesia juga hukum Islam yang mewajibkan setiap negara taat pada pimpinannya. Sebagaimana dalam surat annisa ayat 59 yang 
artinya“ wahai orangorang yang beriman taatilah Allah, Taatilah rasul, taatilah ulil amri diantara kamu .......”(Q.S An-Nisa :59). Maka dari pengertian diatas dapat disimpulkan bahwa pernikahan siri dapat dikatakan tidak sah karena pencatatan pernikahan termasuk dalam pasal keabsahan pernikhan, sehingga setiap pernikahan yang tidak dicatatkan dianggap tidak sah menurut negara Indonesia, sesuai pasal 1 ayat 2 UU Perkawinan No 1 Tahun 1974, ditegaskan dengan Kompilasi Hukum Islam. Dengan demikian di dalam pernikahan siri terdapat peluang adanya tuntutan pidana perzinahan kepada pasangan yang melakukakan pernikahan siri jika salah satu pasangan telah menikah secara sah dengan orang lain.

\section{Bias Gender Dalam Hukum Perkawinan Islam di Indonesia}

Dalam Undang-Undang Perkawinan No. 1 Tahun 1974 dan Kompilasi Hukum Islam terdapat beberapa hukum yang dirasa tidak memberi ruang yang setara terhadap perempuan dan dinilai masih belum memenuhi rasa keadilan dan kemanusiaan, meskipun dilihat dari perkembangan hukum perkawinan telah menunjukkan kemajuan yang berarti. Hal ini terkait dengan beberapa masalah, sebagaimana di kritisi Siti Musdah Mulia dalam beberapa tulisannya, yang pertama; hak mempelai wanita yang digantikan otoritas ijab kabulnya oleh wali dalam perkawinan (Mulia, 2007: 139), kedua, adanya ketentuan harus seagama sehingga sering terjadi konversi semu; karena setelah akad nikah kembali kepada agamanya semula, Ketiga; mengenai batasan usia sebagaimana dalam pasal 7 ayat 1 batas minimal adalah 19 tahun bagi laki-laki dan 16 tahun bagi perempuan, yang dirasa bertentangan dengan UU No. 4 tahun 1979 tentang kesejahteraan anak, yang mana dalam pasal 1 ayat 2 dikatakan bahwa "anak adalah seseorang yang belum umur 21 tahun atau dan belum pernah kawin”, Keempat; masalah pencatatan perkawinan yang tidak adanya tekanan "keharusan” atau adanya sanksi bagi perkawinan yang tidak dicatatkan. Karena perkawinan yang tidak dicatatkan akan berdampak buruk bagi istri dan anak-anak. Kelima; masalah poligami, meskipun dalam hukum perkawinan dikatakan berasas monogami, namun karena beberapa alasan diperbolehkan poligami. Dan dalam UUP No. 1 Tahun 1974 ini terkesan pro poligami karena poligami diatur secara rinci dalam pasal 3, 4, 6, yang mana dalam pasal-pasal tersebut dikonstruksikan untuk kepentingan laki-laki padahal dalam al-Qur’an konteksnya adalan pembicaraan anak yatim (Mulia, 2007: 88140).

Maka menurut pandangan para tokoh berperspektif gender, masalah perkawinan yang terdapat dalam UUP No. 1 Tahun 1974 merupakan bentuk-bentuk pandangan dan pengkonsepsian yang secara kultural dan sosiologis telah melakukan diskriminasi terhadap 
perempuan (Mulia, 2007). Diskriminasi terhadap perempuan tersebut terjadi karena ketimpangan gender, yaitu konstruksi sosial dan kultural yang membedakan peran, perilaku, mentalitas, dan karakteristik emosional antara laki-laki dan perempuan yang berkembang di masyarakat (Fakih,1999).

Sedangkan dalam ajaran Islam, posisi laki-laki dan perempuan adalah setara sebagai manusia, makhluk yang mempunyai tugas sebagai hamba dan khalifah Allah di muka bumi. Hal ini didasarka pada beberapa ayat al-Qur'an seperti surat Shad (38:71), surat Yunus (10:44), alBaqoroh (2:48) dan masih banyak lagi ayat al-qur'an yang menyiratkan adanya kesetaraan lakilaki dan perempuan dalam meningkatkan kualitas iman dan perbuatan baiknya dalam tugas kemanusiaan di bumi. Perbedaannya hanya menunjuk pada aspek biologis, yang mana dalam ajaran islam perbedaan biologis tidak bisa dijadikan alasan untuk melakukan diskriminasi (Mulia, 2007:). Oleh karena itu jika terjadi produk hukum (fikih) yang tidak sensitif dengan hakekat tujuan syari’ah, maka perlu dilakukan pembaharuan. Hal ini didasarkan pada beberapa hal pokok yaitu: pertama, hakekatnya Islam sendiri sebagai bentuk respon sosial terhadap masyarakat, kedua Islam sebagai ajaran yang menjanjikan kebahagiaan dan kesejahteraan bagi manusia.

Demikian juga kehadiran Kompilasi Hukum Islam merupkan salah satu kelengkapan kelembagaan Peradilan Agama yang memegang kompetensi hukum kekeluargaan Islam yang telah diundangkan terlebih dahulu, sehingga bagaimana sebuah peradilan dapat beroperasi secara wajar, adil dan berkeadilan jika tidak disertai dengan hukum materiil sebagai pegangan yang bersifat unifikatif. Maka kehadirannya merupakan kebutuhan yang tidak dapat ditawar-tawar lagi bagi tegaknya kelembagaan Peradilan Agama.

Namun untuk memenuhi segala kebutuhan hukum positif yang dihadapi umat Islam dan pengadilan tidaklah mudah, disebabkan tidak seluruh kasus yang diajukan dalam persidangan itu dapat dirujuk dalam dalil-dalil hukum Islam, sehingga penyusunan Kompilasi inipun mengalami kendala yang sama, apalagi sifat unik budaya dan adat Indonesia yang sangat kental menghiasi praktek hukum kekeluargaan dalam masyarakat. Maka untuk dalil-dalil yang semacam itu ditetapkan dengan landasan maslahah bagi dalil-dalil yang berkategori zanni.

\section{Kesetaraan Gender dan Hak Asasi Manusia}

Berbagai manifestasi ketidakadilan gender, pada dasarnya merupakan refleksi dari ketidakadilan yang terstruktur yang dikonstruk oleh sistema sosial, budaya, atau bahkan agama yang padagilirannya melahirkan pelanggaran Hak Asasi Manusia. Hak ini disebabkan manifestasi ketidakadialan gender tersebut banyak menimpakaum perempuan, maka wacana gender identik dengan kaum perempuan.(Ridwan,2006:33). Berpasangan merupakan ketetapan illahi untuk 
semua makhluk hidup sebagaimana dalam Q.S. AdzDzariyat (51):49, Yasin (36): 36, asy_Syura (42): 11, ar-Rum (30): 21. Pernikahan merupakan keterikatan dua pihak yang dilandasi mawaddah (cinta yang penuh kelapangan terhadap kekurangan pasangannya sebagai bagian hidupnya), rahmah ( kasih sayang dengan perasaan saling memiliki sebagai pilihan yang terbaik), dan sakinah (ketenangan, ketentraman, kekompakan, harmonis dan terbuka).

Dalam ranah hukum islam, perkawinan yang dalam istilah agama disebut “Nikah” ialah melakukan suatu akad atau perjanjian untuk mengikatkan di antara seorang laki-laki dan wanita untuk menghalalkan hubungan kelamin antara kedua belah pihak, dengan dasar sukarela dan keridhoan kedua belah pihak untuk mewujudkan suatu kebahagiaan hidup berkeluarga yang diliputi rasa kasih sayang dan ketentraman dengan cara-cara yang diridhoi oleh Allah (Ahmad Azhar Basyir,1977: 10).

Sajuti Thalib mengatakan bahwa perkawinan ialah suatu perjanjian yang suci dan kuat serta kokoh untuk hidup bersama secara sah antara seorang laki-laki dengan seorang perempuan membentuk keluarga yang kekal, santun-menyantuni, kasih mengasihi, tenteram dan bahagia..(Idris Ramulyo, 1996: 2)

Dalam al-Qur'an pernikahan adalah status suami istri yang diikat dalam ijab-qabul dianggap merupakan perjanjian yang kokoh antara dua manusia, mitsaqonGalidhan (Q.S anNisa (4):21 dan al-Ahzab (33):7). Hukum pernikahan menurut sebagian besar ulama adalah sunnah, ulama dhahiriyyah menyebutkannya wajib, sebagian ulama Malikiyah mengatakan bahwa hukum pernikahan ada tiga yaitu wajib, bagi orang yang tidak dapat mengendalikan hawa nafsu; sunnah, bagi yang menginginkannya; dan mubah, bagi yang tidak begitu menginginkannya. Semuanya bergantung pada ada tidaknya kebaikan khususnya bagi pelakunya dan umumnya bagi seluruh umat manusia(Ibnu Rusyd, 1960:2).Sedangkan kaum muslim Indonesia yang mayoritas bermazhab Syafi'iyah menetapkan hukum perkawinan sebagai sunnah mu'akkadah Yaitu anjuran yang hampir mendekati kewajiban. Bagi mereka yang telah dewasa, baik lelaki maupun wanita penting untuk menikah.

Menurut Undang-Undang Nomor 1 Tahun 1974 tentang perkawinan pada Pasal 1, perkawinan ialah ikatan lahir batin antara seorang pria dengan seorang wanita sebagai suami istri dengan tujuan membentuk keluarga (rumah tangga), yang bahagia dan kekal berdasarkan Ketuhanan Yang Maha Esa. Pertimbangannya adalah sebagai negara yang berdasarkan Pancasila di mana sila pertamanya ialah Ketuhanan Yang Maha Esa, maka perkawinan mempunyai hubungan yang erat sekali dengan agama atau kerohanian sehingga perkawinan bukan saja 
mempunyai unsur lahir atau jasmani tetapi unsur batin atau rohani juga mempunyai peranan yang penting.

Perkawinan menurut Kompilasi Hukum Islam adalah pernikahan, yaitu akad yang sangat kuat atau miitsaaqan ghaliizhan untuk menaati perintah Allah dan melaksanakannya merupakan ibadah. Dan perkawinan bertujuan untuk mewujudkan kehidupan rumah tangga yang sakinah, mawadah dan warohmah. Keabsahan perkawinan sebagaimana dalam UndangUndang No 1 Tahun 1974 dalam Pasal 2 ayat (1) dan Pasal 2 (2) yang menetapkan sebagai berikut:

Perkawinan adalah sah, apabila dilakukan menurut hukum masing-masing agamanya dan kepercayaannya itu. Tiap-tiap perkawinan dicatat menurut peraturan-peraturan, perundangundangan yang berlaku (Asnawi Mohammad, 1975232).

Demikian juga dalam Kompilasi Hukum Islam (KHI) dikatakan bahwa keabsahan Perkawinan adalah apabila dilakukan menurut hukum Islam sesuai pasal 2 ayat $1 \& 2$ UU.NO.1 tahun 1974, dan dicatat oleh PPN. Dengan demikian, selain harus memenuhi syarat dan rukun perkawinan sebagaimana ketetapan dalam hukum islam, juga harus di dicatatkan di Kantor Urusan Agama (KUA) oleh Pegawai Pencatat Nikah (PPN). Pencatatan nikah ini memiliki arti jaminan kepastian hukum atas status pernikahan dengan segala akibat yang ditimbulkannya. Maka pencatatan merupakan suatu keharusan, dan kebutuhan primer yang harus dipenuhi bagi setiap pasangan suami istri, sehingga hak-hak masing-masing dijamin secara hukum.

Hal ini berbeda dengan makna pernikahan siri, yang dalam fikih memiliki arti nikah yang disembunyikan, dirahasiakan, dan tidak diumumkan ke dunia luar (Wahbah Zuhaily,VII:71) Sedang dalam pengertian yuridis di Indonesia, pernikahan siri adalah pernikahan yang dilakukan secara hukum islam dengan diketahui orang banyak, hanya saja tidak dicatatkan ke Kantor Urusan Agama, sehingga yang membedakan antara nikah sirri dan bukan adalah akta nikah sebagai bukti atas adanya pernikahan. Maka menurut Quraish Shihab nikah siri adalah sah menurut hukum Islam, tetapi dapat mengakibatkan dosa bagi pelakunya, karena melanggar ketentuan pemerintah”Aturan ulil amri harus ditaati selama tidak bertentangan dengan hukumhukum Allah (Quraish Shihab, 2007:271).

Hukum perkawinan Islam telah dilakukan jauh sebelum adanya Undang-Undang tentang pencatatan sebagai syarat legalnya perkawinan, sehingga perkawinan secara islam telah menjadi budaya di masyarakat dan telah mengakar menjadi hukum adat, maka hal yang cukup sulit untuk mengatasi permasalahan perkawinan siri yang telah dianggap sah secara hukum islam tersebut 
meski hal tersebut telah banyak menimbulkan berbagai problematika dimana hak-hak mereka yang melakukan perkawinan siri tidak terlindungi hukum, karena secara legal formal mereka belum menikah. Di Indonesia telah terdapat sejumlah Undang-Undang dan Peraturan PerundangUndangan lainnya yang secara legal bisa dijadikan ukuran keabsahan pernikahan. Diantaranya Secara yuridis, upaya perlindungan kaum perempuan dari ketidakadilan gender dipayungi oleh landasan yuridis yaitu Deklarasi Universal Hak Asasi Manusia (DUHAM) Majlis Umum PBB tanggal 18 Desember 1948, kemudian dijabarkan secara spesifik melalui konvensi PBB tentang penghapusan segala bentuk diskriminasi terhadap perempuan tanggal 18 Desembar 1979. Pada tingkat lokal masing-masing negara yang meratifikasi DUHAM dan Konvensi PBB tersebut kemudian menjabarkannyalebih lanjut sesuai dengan kebutuhan masing-masing negara termasuk Indonesia.

Landasan idiil penegakan HAM di Indonesia tertuang dalam pembukaan UUD 1945 dan Deklarasi Universal HAM (DUHAM). Pembukaan UUD 1945 merupakan pernyataankeyakinan bahwa kemerdekaan adalah hak semua bangsa. Sejak dideklarasikan oleh PBB pada tanggal 18 Desember 1948 HAM telah mendapatkan pengakuan dan perlindungan penuh, sebagaimana yang terdapat dalam pasal-pasal Duham dapat ditemukan betapa martabat manusia dihargai sangat tinggi namun demikian dalam tataran praktis masih menyisakan masalah terutama kaitannya dengan diskriminasi terhadap perempuan. Kaum perempuan pada umumnya masih diposisikan sebagai manusia 'kelas dua' (second man) dalam berbagai dimensi kehidupan.

Berdasarkan realitas obyektif adanya diskriminasi terhadap perempuan, maka Majlis Umum PBB pada tanggal 18 Desembar 1979 mengeluarkan sebuah instrumen intrnasional bagi perlindungan perempuan yang dikenal dengan konvensi perempuan. Atau Billof right (UU HAM) bagi perempuan yang isinya menetapkan stándar-stándar yang dapat diterima secara international guna mencapai kesetaraan hak mereka dengan kaum laki-laki. Negara yang meratifikasi konvensi perempuan mengakui bahwa diskriminasi terhadap kaum perempuan adalah problema sosial yang perlu diselesaikan.

\section{Perspektif Gender Sebagai Model Reformulasi Perkawinan Islam di Indonesia}

Aktifis pembela hak-hak perempuan, Nursjahbani Katjasungkana, termasuk yang banyak mengkritik Undang-Undang Perkawinan. Bahkan, Direktur LBH APIK mengungkapkan bahwa UU Perkawinan ini perlu ditinjau kembali, tidak saja dalam perspektif relasi yang lebih adil bagi perempuan dan laki-laki, tapi juga dalam konteks globalisasi saat ini. "Jika tidak, akan menimbulkan berbagai persoalan yang dapat menyebabkan diintegrasi dalam masyarakat," 
ujarnya. Nursjahbani menyatakan bahwa GBHN telah mengamanatkan untuk meningkatkan kedudukan danperanan perempuan dalam berbagai aspek kehidupan bernegara dan berbangsa untuk mewujudkan kesetaraan dan keadilan gender. Nursjahbani menambahkan, komitmen ini sebenarnya sudah sejak lama dinyatakan oleh pemerintah saat meratifikasi konvensi penghapusan segala bentuk diskriminasi terhadap perempuan dengan UU No 7 Tahun 1984 . Komitmen-komitmen ini juga diberikan oleh Indonesia dalam hasil-hasil Konferensi Beijing pada 1995. Dari kerangka ini, Nursjahbani berpendapat bahwa mau tidak mau segala produk hukum yang bertentangan dengan berbagai kesepakatan dan hukum internasional haruslah diubah. "Jika tidak, Indonesia akan dicap tidak memenuhi kewajiban hukumnya menurut ketentuan hukum internasional," ujar Nursyahbani

Undang-Undang Perkawinan tahun 1974 yang mengatur tentang perkawinan sudah dianggap sebagai Undang-Undang yang tidak lagi relevan dengan kondisi dan kebutuhan masyarakat saat ini terutama bagi perempuan. Karena UndangUndang perkawinan 1974 merupakan produk Undang-Undang yang memiliki dampak diskriminatif, khususnya bagi perempuan. Diantaranya bisa dilihat dalam BAB I ps. 4 ayat (1) yang berbunyi: Dalam hal seorang suami yang akan beristeri lebih dari seorang, seperti tersebut dalam ps. 3 ayat (2) Undang-undang ini, maka ia wajib mengajukan permohonan kepada pengadilan di daerah tempat tinggalnya.

Kemudian diperjelas lagi dalam ps. 4 ayat (2) yang berbunyi : pengadilan yang dimaksud dalam ayat (1) pasal ini hanya memebrikan izin kepada seorang suami yang akan beristeri lebih dari seorang meliputi :

a. Isteri tidak dapat menjalankan kewajiban sebagai isteri.

b. Isteri mendapat cacat badan atau penyakit yang tidak bisa disembuhkan.

c. Isteri tidak dapat melahirkan keturunan.

Pasal dan Ayat tersebut jelas-jelas menyebutkan betapa Negara telah melakukan tindak diskriminatif secara tidak langsung terhadap serorang isteri yang notabene adalah seorang perempuan dengan mengatakan point seperti tersebut di atas, kondisi ini kemudian menimbulkan pertanyaan, bagaimana jika kondisi dalam suatu rumah tangga justru bertolak belakang dari pointer-pointer diatas, suami cacat, suami tidak bisa memenuhi kewajibanya sebagai suami bahkan suami tidak bisa memberikan keturunan karena mandul. Jika terjadi sebaliknya, apakah pengadilan juga akan mengijinkan seorang perempuan menikah lagi dengan laki-laki lain (poliandri) karena alasan-alasan tersebut di atas? Ini yang harusnya direnungkan. Sebagaimana yang telah kita ketahui bahwa beberapa rancangan Undang-Undang yang telah masuk dalam 
pembahasan Program Legislative Nasional (Prolegnas) adalah RUU Hukum Materiil Peradilan agama (RUU HMPA). Tentunya ini menjadi angin segar bagi kita bersama, jika memang benar rancangan Undang -Undang tersebut dapat menjadi alat yang akan mewakili rasa keadilan kita sebagai warga Negara yang berharap untuk segera disahkan, terutama dalam bidang perkawinan, jika memang draft RUU tersebut telah sesuai dengan keinginan dan kondisi masyarakat pada umumnya, dan bukan hanya segelintir kelompok saja yang diuntungkan.

Namun demikian RUU HMPA yang di harapkan memberikan perubahan dalam sistem perundang-undangan yang lebih baik ternyata masih terdapat ketidakseimbangan dalam konsep keadilan bagi semua pihak, baik dalam aspek umum, bahwa undang-undang menjamin hak-hak seluruh warga Negara, tidak memandang dari sudut agama atau suku apapun ataupun khususnya memberikan perlindungan bagi perempuan dan anak yang cukup rentan terhadap tindak diskriminasi. Oleh karena itu, RUU HMPA diharapkan dapat kembali dicermati dari mulai pasal perpasal, agar dapat diketahui dimana letak kekurangan dan kelebihan dari draft tersebut. Sehingga makna dan subtansi dari tujuan perancangan sebuah Undang-undang untuk melindungi warga negaranya tidak menjadi kabur.

\section{E.Simpulan}

1. Beberapa kelemahan Dalam pasal-pasal UU. No. 1 tahun 1974 dan Kompilasi hukum Islam terutama yang berkaitan dengan isu Gender dan HAM, diantaranya berimbas pada maraknya kasus perkawinan siri.Keabsahan Perkawinan di Indonesia sebagaimana dalam KHI adalah apabila dilakukan menurut hukum Islam sesuai pasal 2 ayat 1\&2 UU.NO.1 tahun 1974, dan dicatat oleh PPN. Pencatatan nikah ini memiliki arti jaminan kepastian hukum atas status pernikahan dengan segala akibat yang ditimbulkannya. Sedang pernikahan siri yaitu pernikahan yang tidak dicatatkan pada lembaga yang berwenang, dianggap tidak sah menurut ketentuan negara, meskipun secara hukum islam pernikahan tersebut sah. Apalagi jika mendasarkan pertimbangan pada sumber hukum islam yang terdapat dalam surat anNisa ayat 59 untuk selain berpegang pada al-Qur’an, Hadist, juga harus taat kepada Ulul Amri atau pemerintahan yang sah. Padahal pencatatan merupakan salah satu syarat yang sudah ditetapkan untuk keabsahan suatu perkawinan. Oleh karena itu perkawinan siri merupakan salah satu bentuk pelecehan terhadap lembaga perkawinan. Hal ini juga dikarenakan belum adanya ketentuan sanksi pidana dalam perundang-undangan ini.

2. Rancangan Undang-Undang Hukum Materii Peradilan Agama (RUU HMPA) merupakan model yang ditawarkan dan diharapkan sebagai pemecah kebuntuan hubungan antara agama 
dan kebudayaan. Khususnya untuk memberikan perlindungan bagi perempuan dan anak yang cukup rentan terhadap tindak diskriminasi.Keterlibatan isu-isu kemanusiaan dalam ilmu-ilmu sosial seperti Isu-isu gender, HAM, lingkungan hidup, kearifan lokal dan lain-lain yang dijadikan sebagai pertimbangan dalam perumusan RUU-HMPA ini merupakan perkembangan positif yang dicapai dalam pembangunan hukum di Indonesia.Hal ini merupakan realitas yang dihasilkan dari proses dinamika sosial yang berlaku dalam masyarakat. Oleh sebab itu sebaiknya dapat dilihat dengan bijaksana sebagai faktor-faktor yang mendukung keberlakuan hukum. Inilah model kebijaksanaan dalam pembangunan hukum nasional Indonesia. Meski demikian RUU HMPA yang kita harapkan memberikan perubahan dalam system perundangundangan yang lebih baik ternyata masih terdapat ketidakseimbangan dalam konsep keadilan, oleh sebab itu perlu dicermati secara lebih mendalam dan menyeluruh supaya dapat memenuhi rasa keadilan bagi segenap warga Indonesia.

\section{F.Saran-Saran}

a. Penelitian ini diharapkan bisa menjadi masukan bagi masyarakat akan pentingnya pencatatan nikah dan bahayanya pernikahan siri, yang dalam kenyataan dalam masyarakat telah banyak mendatangkan kemadlorotan terutama bagi perempuan dan anak-anak yang dilahirkan.

b. Melihat banyaknya kasus-kasus dalam pernikahan penulis berharap kepada pemerintah untuk segera menyempurnakanRUUHMPA dan mensahkannya sebagai perundangundangan yang diharapkan bisa melindungi seluruh warga Negara Indonesia terutama hakhak kaum wanita dan anak-anak.

\section{Daftar Pustaka}

Azhar Basjir. 1977. Hukum Perkawinan Islam.Yogyakarta:UII Press.

Badan Legislasi DPR RI, 2002, Undang-Undang RI tentang PerkawinanAhmad Rofiq, 2000, Hukum Islam Di Indonesia. Jakarta: PT Raja Grafindo Persada.

Badriyah Fayumi. 1993. Perempuan dalam fikih Munakahat, catatan atas problematika. Jakarta: Seminar Majlis Tarjih Muhammadiyah

Departemen Agama. 1995. Al-Qur'an al-Karim. Jakarta: Proyek Pengadaan Mushaf alQur'an. 
Depag RI. 1991. Undang-Undang No 7 Tahun 1989 Tentang Peradilan Agama Dan Kompilasi Hukum Islam. Surabaya: Pustaka Tirtamas .

Farcha Ciciek. 1999. Ikhtiar Mengatasi Kekerasan Dalam Rumah Tangga;

Belajar dari Kehidupan Rasulullah SAW, Lembaga Kajian Agama dan Gender. Jakarta: Solidaritas Perempuan dan The Asia Foundation.

Fatima Mernisi. 1999. Pemberontakan Wanita: Peran Intelektual Kaum Wanita Dalam Sejarah Muslim. Bandung: Mizan,

Neng Djubaidah. 2010. Perzinaan Dalam Perundang-Undangan Di Indonesia. Jakarta:Kencana.

Ibn Rusyd. 1960. Bidayah al-Mujtahid wa Nihayah al-Muqtasid. Mesir:Syirkah maktabah wa Mathba'ah Musthafa alBabi al-Halabi wa Awladuh

Mansoer Fakih. 1995. Analisa Gender dalam Transformasi Sosial, Yogyakarta: Pustaka Pelajar.

Hilman Hadikusuma. 1990. Hukum Perkawinan Indonesia Menurut Perundang Hukum Adat dan Hukum Agama. Bandung: Mandar Maju.

Ibn Rusyd al-Qurtubi. Tt. Bidayah al-Mujtahid wa Nihayah al-Muqtasid. Jeddah: AlHaramain li al-Thiba'ah wa al-Nasyr wa al- Tawzi'

Sayyid Sabiq . 1973. Fiqh Sunnah. Beirut: Darul al-Kitab al’Arabi.

Wahbah al Zuhaily. 1989. Al-Fiqh al-Islamy wa Adillatuhu, Beirut: Dar al-Fikr. 